Yayah Khoeriah, Sri Dinengsih, Risza Choerunnisa

\title{
ANALISIS KUALITAS PELAYANAN ANTENATAL CARE (ANC) TERHADAP TINGKAT KEPUASAN IBU HAMIL DI POLI KEBIDANAN
}

\author{
Yayah Khoeriah ${ }^{1}$, Sri Dinengsih ${ }^{2 *}$, Risza Choerunnisa ${ }^{3}$ \\ ${ }^{123}$ Program Studi Sarjana Terapan Kebidanan Universitas Nasional \\ Email : yayahkhoeriah85@gmail.com \\ *Korespondensi : sridinengsih@civitas.unas.ac.id
}

\section{ABSTRACT QUALITY ANALYSIS OF ANTENATAL CARE(ANC) SERVICES ON THE SATISFACTION LEVEL OF PREGNANT MOTHERS IN OBJECTIVE POLICIES}

Background In Indonesia, the quality of ANC services is still low, seen from the coverage of ANC which is still below the national target where data on the coverage of pregnant women (K4) visits in Indonesia in 2015 was $87.48 \%$, which means it has not reached the target of the Strategic Plan of the Ministry of Health in 2015, namely by $95 \%$. Of the 34 provinces in Indonesia, only 3 provinces have achieved this target, namely the Riau Archipelago, DKI Jakarta, and West Java.

The Purpose To know the relationship between the quality of antenatal care (ANC) services to the level of satisfaction of pregnant women in the obstetrics poly

The research design method uses an analytical survey research with a cross-sectional approach, the number of samples is 83. The research instrument uses a questionnaire, bivariate analysis uses the Chi Square test.

Results Based on data from 83 pregnant women who were dissatisfied with ANC services as many as 15 people (18.1\%), based on Tangibles less good and dissatisfied 16 (19.3\%), Empathy 16 (19.3\%)

The conclusion is that there is a relationship between satisfaction with Tangibles $(P$-value $=0.000 O R$ 140.80), Reliability ( $P$-value $=0.000$ OR 86.66), Responsiviness $(P$-value $=0.000$ OR 303.3), Assurance ( $P$-value $=0.000$ OR 140.8) and Empathy (P-value $=0.000$ OR 140.8)

Suggestions It is hoped that health workers will improve counseling for pregnant women to conduct regular ANC visits.

Keywords: Quality of service, ANC, level of satisfaction

\section{ABSTRAK}

Latar Belakang Di Indonesia, kualitas pelayanan ANC masih rendah dilihat dari cakupan ANC yang masih dibawah target nasional dimana data cakupan kunjungan ibu hamil (K4) di Indonesia pada tahun 2015 sebesar 87,48\% yang berarti belum mencapai target Renstra Kementerian Kesehatan pada tahun 2015 yaitu sebesar $95 \%$. Dari 34 provinsi di Indonesia, hanya 3 provinsi yang telah mencapai target tersebut, yaitu kepulauan Riau, Dki Jakarta, dan jawa barat.

Tujuan Diketahui hubungan kualitas pelayanan antenatal care(anc) terhadap tingkat kepuasan ibu hamil di poli kebidanan

Metode desain penelitian ini menggunakan penelitian survey analitik dengan pendekatan cross- sectional, jumlah sampel 83. instrument penelitian menggunakan kuesioner, analisis bivariate menggunakan uji Chi Square.

Hasil Berdasarkan data 83 ibu hamil yang tidak puas terhadap pelayanan ANC sebanyak 15 orang (18,1\%), berdasarkan Tangibles kurang baik dan tidak puas 16(19,3\%), Emphaty $16(19,3 \%)$

Kesimpulan adanya hubungan kepuasan dengan Tangibles ( $P$-value $=0,000$ OR 140,80), Reliability (Pvalue $=0,000$ OR 86,66), Responsiviness ( $P$-value $=0,000$ OR 303,3), Assurance (P-value $=0,000$ OR 140,8)dan Emphaty (P-value $=0,000$ OR 140,8)

Saran Diharapkan kepada petugas kesehatan supaya meningkatkan konseling terhadap ibu hamil untuk melakukan kunjungan ANC secara teratur.

Kata Kunci: Kualitas pelayanan, ANC, tingkat kepuasan 


\section{JKM (Jurnal Kebidanan Malahayati),Vol 7,No.4.Oktober 2021, \\ ISSN (Print) 2476-8944 ISSN (Online) 2579-762X, Hal 620-625}

\section{PENDAHULUAN}

Kepuasan pasien merupakan hasil penilaian dari pasien bahwa produk atau pelayanan telah memberikan tingkat kenikmatan dimana tingkat pemenuhan ini bisa lebih atau kurang. Pasien akan merasa puas jika persepsinya sama atau lebih dari yang diharapkan. Kepuasan pasien ditentukan oleh persepsi pasien atas performance jasa dalam memenuhi harapan pasien, dengan tingkat pelayanan pada pelayanan kesehatan akan mempengaruhi angka kunJungan ibu hamil dengan demikian masalah kesehatan pada ibu hamil akan muncul. (Umaternate,2015)

ANC merupakan kunjungan ibu hamil dengan tenaga kesehatan untuk mendapatkan pelayanan ANC sesuai dengan standar yang ditetapkan. Dalam hal ini, istilah kunjungan tidak hanya mengandung arti bahwa ibu hamil yang datang ke fasilitas pelayanan, tetapi setiap ibu hamil yang melakukan kontak dengan tenaga kesehatan, baik di posyandu, pondok bersalin desa, dan kunjungan rumah dapat dianggap sebagai kunjungan ibu hamil(Sundari L,2017)

Indikator kualitas capaian pelayanan kesehatan ibu hamil dapat dinilaidari cakupan kunjungan ibu hamil (K4). Indikator cakupan K4 memperlihatkan akses pelayanan kesehatan terhadap ibu hamil dan tingkat kepatuhan ibu hamil dalam memeriksakan kehamilannya ke tenaga Kesehatan(Izati,2018)

Cakupan K4 juga dapat menggambarkan cakupan pertolongan persalinan oleh tenaga kesehatan. Diasumsikan bahwa ibu hamil yang mendapatkan pelayanan antenatal K4 kemungkinan persalinannya akan ditolong tenaga kesehatan. Diharapkan dengan meningkatkan cakupan pelayanan kesehatan ibu hamil K4 akan meningkatkan cakupan pertolongan persalinan oleh tenaga kesehatan (Florensia L,2021)

Di Indonesia, kualitas pelayanan ANC masih rendah dilihat dari cakupan ANC yang masih dibawah target nasional dimana data cakupan kunjungan ibu hamil (K4) di Indonesia pada tahun 2015 sebesar $87,48 \%$ yang berarti belum mencapai target Renstra Kementerian Kesehatan pada tahun 2015 yaitu sebesar 95\%. Dari 34 provinsi di Indonesia, hanya 3 provinsi yang telah mencapai target tersebut, yaitu kepulauan Riau, DKI Jakarta dan Jawa Barat (Profil Kesehatan Indonesia,2019)

Kunjungan Ibu Hamil Pertama pada umur kehamilan 0-3 bulan (K1) di Provinsi Jawa Barat tahun 2017, sebanyak 986.561Bumil dari sasaran
971.458Bumil (101,6\%), dan Kunjungan K4 sebanyak 942.077 Bumil $\quad(97,0 \%)$, terdapat 44,484Bumil yang mangkir (Dropout) pada pemeriksaan ke 4 (4.51\%). (Profil Kesehatan Indonesia,2019)

Ketidakpuasan pasien masih sangat tinggi dan bukan hanya negara lain akan tetapi juga di Indonesia, banyak penyebab dari ketidakpuasan pelayanan antenatal ini seperti peralatan atau alatalat komunikasi, kemampuan dalam melakukan tindakan pelayanan, pelayanananya yang cepat dan tepat, sikap dalam melakukan pelayanan dan komunikasi dalam melakukan pelayanan. (Maulana,2017)

Ketidakpuasan pasien dengan pelayanan yang diberikan akan dapat menyebabkan pasien pergi ke tempat fasilitas pelayanan yang lain atau bahkan membuat pasien pergi ke tenaga non nakes. Hal ini salah satu penyebab tidak langsung dari tingginya angka kematian ibu, karna apabila pasien tidak merasa puas dengan pelayanan yang didapatkan maka pasien bisa pergi ke tenaga non nakes sehingga bisa mengakibatkan terjadinya komplikasi pada pasien yang dikarenakan tidak terdekteksinya resiko tinggi pada pasien (Maulana,2017).

Studi pendahuluan yang dilakukan peneliti di Poli Kebidanan RSAU dr.HOEDIYONO Lanud Suryadarma kunjungan ANC dari bulan Januari Mei Tahun 2021 sebanyak 105 ibu hamil,11 (10\%) ibu hamil mengatakan kurang puas dengan pelayanan ANC di RSAU dr.HOEDIYONO Lanud Suryadarma

\section{METODE PENELITIAN}

Menggunakkan dengan metode survey analitik dengan pendekatan cross- sectional. Instrument penelitian menggunakkan, kuisioner analisis bivariate menggunakan uji Chi Square. Dengan tujuan untuk mengetahui Analisis kepuasan ibu hamil terhadap pelayanan ANC di poli kebidanan RSAU dr. HOEDIYONO Lanud Suryadarma Tahun 2021.

Populasi seluruh ibu hamil di RSAU dr. HOEDIYONO Lanud suryadarma pada bulan Januari-Mei 2021 sebanyak 105 orang. Besar sampel sebagian ibu hamil jadi metode yang di gunakan dalam pengambilan sampel adalah accidental sampling. Instrumen penelitian menggunakan kuesioner. Uji analisis dengan Chi Square. 


\section{HASIL DAN PEMBAHASAN}

Analisis univariat

Tingkat Kepuasan

Table 1

Dimensi kepuasan pelayanan ANC, pada ibu hamil mengatakan puas sebanyak 68 orang $(81.9 \%)$ dan ibu hamil mengatakan tidak puas sebanyak 15 orang ( $18.1 \%)$

\begin{tabular}{lccc}
\hline & Kepuasan & F & $(\%)$ \\
\hline Puas & & 68 & 81.9 \\
Tidak Puas & & 15 & 18.1 \\
\hline \multicolumn{2}{c}{ Total } & 83 & 100 \\
\hline
\end{tabular}

\section{Analisis Bivariat}

Table 2

Tingkat kepuasan ibu hamil

\begin{tabular}{|c|c|c|c|c|c|c|c|c|}
\hline \multirow{2}{*}{ Tangible } & \multicolumn{4}{|c|}{ Kepuasan } & \multirow{2}{*}{ Total } & \multirow{2}{*}{$\%$} & \multirow{2}{*}{$P$} & \multirow{2}{*}{ OR } \\
\hline & Puas & $\%$ & Tidak & $\%$ & & & & \\
\hline Baik & 65 & 97,0 & 2 & 3,0 & 67 & 100 & 0.000 & \\
\hline $\begin{array}{l}\text { Kurang Baik } \\
\text { Realibility }\end{array}$ & 3 & 18,8 & 13 & 81,2 & 16 & 100 & & 140.8 \\
\hline Baik & $\begin{array}{l}65 \\
65\end{array}$ & $\begin{array}{l}95.6 \\
95,6\end{array}$ & 3 & 4.4 & 68 & 100 & 0.000 & \\
\hline $\begin{array}{l}\text { Kurang Baik } \\
\text { Responsivenees }\end{array}$ & 3 & 20.0 & 12 & 80. & 15 & 100 & & 8.60 \\
\hline Baik & 63 & 95.5 & 3 & 4.1 & 68 & 100 & & \\
\hline $\begin{array}{l}\text { Kurang Baik } \\
\text { Assurance }\end{array}$ & 5 & 29.4 & 12 & 70.6 & 15 & 100 & 0.000 & 50.40 \\
\hline Baik & 65 & 97,0 & 2 & 3,0 & 67 & 100 & & \\
\hline $\begin{array}{l}\text { Kurang } \\
\text { Empaty }\end{array}$ & 3 & 18.8 & 13 & 81.2 & 16 & 100 & 0.000 & 140.8 \\
\hline $\begin{array}{l}\text { Baik } \\
\text { Kurang }\end{array}$ & 65 & 78.3 & 2 & 2.4 & 67 & 80.7 & 0.000 & 140.8 \\
\hline
\end{tabular}

\section{PEMBAHASAN}

\section{Tingkat Kepuasan Ibu Hamil}

Berdasarkan table 1 Dimensi kepuasan pelayanan ANC, pada ibu hamil mengatakan puas sebanyak 68 orang (81.9\%) dan ibu hamil mengatakan tidak puas sebanyak 15 orang ( $18.1 \%)$

Kepuasaan pasien merupakan hasil dari penilaian dari pasien bahwa produk atau pelayanan telah memberikan tingkat kenikmatan dimana tingkat pemenuhan ini bisa lebih atau kurang. Pasien akan merasa puas jika persepsinya sama atau lebih dari yang diharapkan. Kepuasan pasien ditentukan oleh persepsi pasien atas performance jasa dalam memenuhi harapan pasien.(Nissa A,2013)

Kualitas pelayanan antenatal dapat diukur dengan membandingkan persepsi antara pelayanan yang diharapkan dengan pelayanan yang diterima dan dirasakan oleh ibu hamil(Nissa A,2013)

Ketidakpuasan pasien masih sangat tinggi dan bukan hanya negara lain akan tetapi juga di Indonesia, banyak penyebab dari ketidakpuasan pelayanan antenatal ini seperti peralatan atau alatalat komunikasi, kemampuan dalam melakukan tindakan pelayanan, pelayanananya yang cepat dan tepat, sikap dalam melakukan pelayanan dan komunikasi dalam melakukan pelayanan. (Maulana,2017)

Ketidakpuasan pasien dengan pelayanan yang diberikan akan dapat menyebabkan pasien pergi ke tempat fasilitas pelayanan yang lain atau bahkan membuat pasien pergi ke tenaga non nakes. Hal ini salah satu penyebab tidak langsung dari tingginya angka kematian ibu, karna apabila pasien tidak merasa puas dengan pelayanan yang 


\section{JKM (Jurnal Kebidanan Malahayati),Vol 7,No.4.Oktober 2021, \\ ISSN (Print) 2476-8944 ISSN (Online) 2579-762X, Hal 620-625}

didapatkan maka pasien bisa pergi ke tenaga non nakes sehingga bisa mengakibatkan terjadinya komplikasi pada pasien yang dikarenakan tidak terdekteksinya resiko tinggi pada pasien (Maulana,2017

\section{Hubungan Tangible dengan Tingkat Kepuasan Ibu Hamil}

Berdasarkan table 2 dimensi mutu Tangible dengan nilai $p=0,000$ maka ada hubungan yang bermakna antara tangible dengan tingkat kepuasan pada ibu hamil dalam menerima pelayanan ANC dengan nilai OR 140,8 yang dapat di artikan jika pelayanan ANC tidak baik maka akan berpeluang sebesar 140,8 kali ibu hamil merasa tidak puas dengan pelayanan ANC yang diteriamnya, Tangible meliputi penampilan fisik dari fasilitas, peralatan, karyawan dan alat-alat komunikasi

Kepuasan konsumen terhadap suatu produk tergantung dengan bukti langsung yang didapatkan seperti kelengkapan alat, kapasitas kualitas produk dan dukungan peralatan yang baik Kenyamanan fasilitas berkaitan dengan pelayanan kesehatan yang tidak berhubungan langsung dengan efektifitas klinis, tetapi dapat mempengaruhi kepuasan pasien dan bersedia untuk kembali ke fasilitas pelayanan kesehatan untuk memperoleh pelayanan berikutnya ( Mursyidah,2012)

Salah satu faktor yang dapat meningkatkan kualitas pelayanan ANC yaitu dengan mengukur kepuasan pasien, kepuasan pasien tergantung dengan bukti layanan langsung yang didapatkan selama melakukan pelayanan seperti kelengkapan alat yang digunakan memadai, kebersihan alat yang digunakan, dan suasana perawatan yang nyaman, sehingga dapat mempengaruhi pasien untuk datang kembali ke tempat yang sama untuk memperoleh pelayanan berikutnya (Putri,2021)

\section{Hubungan Realibility Dengan Tingkat Kepuasan Ibu Hami}

Kualitas pelayanan ANC dengan realibility nilai $P$ : $(0.000)$ yang artinya ada hubungan yang signifikan antara kualitas pelayanan antenatalcare realibility dengan tingkat kepuasan ibu hamil dengan nilai OR 86 dapat disimpulkan bahwa kualitas pelayanan antenatalcare realibility yang kurang baik mempunyai kecenderungan untuk mengalami ketidakpuasan 86 kali lebih besar dibandingkan dengan kualitas pelayanan antenatal care realibility yang baik.

Persepsi reliability dapat ditinjau dari kemampuan petugas memberikan pelayanan ANC dengan benar, seperti kemampuan petugas dalam pemeriksaan fisik, obstetri, laboratorium, status gizi dan pemberian tablet tambah darah. Mursyidah,2012)

Dengan kualitas yang tinggi akan meningkatkan kepuasan pasien, selanjutnya pasien akan berkunjung ulang pada pelayanan yang sama( Mursyidah,2012)

Pelayanan pada ibu hamil sangat penting, selama ibu tersebut melakukan kunjungan maka berikan pelayanan yang bermutu sehingga ibu hamil akan mendapatkan kepuasan dalam pelayanan dengan melakukan pelayanan sesuai dengan standar profesi dan kode etik yang telah ditetapkan yaitu sesuai dengan standar pelayanan ANC (Sampouw, N. L.2018)

\section{Hubungan Responsiveness Dengan Tingkat Kepuasan Ibu Hamil}

Nilai Responsiveness $p=0,000$ maka ada hubungan yang bermakna antara Responsiveness dengan tingkat kepuasan pada ibu hamil dalam menerima pelayanan ANC dengan nilai OR 50.40 yang dapat di artikan jika pelayanan ANC tidak baik maka akan berpeluang sebesar 50.40 kali ibu hamil merasa tidak puas dengan pelayanan ANC yang diteriamnya , Responsiveness yang diterima seperti memberitahu ibu hamil kapan pelayanan akan diberikan atau kapan harus kembali memeriksakan kehamilannya

Kepuasan dipengaruhi karena Responsiveness, kurangnya cepat tanggap yang terjadi pada petugas dapat menurunkan kualitas pelayanan kesehatan, sehingga bisa menurunkan tingkat kunjungan/jumlah pasien ( Mursyidah,2012)

Jika ibu hamil merasa puas dengan jasa pelayanan yang digunakan maka ibu hamil akan senantiasa untuk melanjutkan menggunakan jasa layanan tersebut. Kurangnya kualitas pelayanan yang diberikan oleh petugas kesehatan seperti ketepatan waktu pelayanan yang meliputi waktu tunggu dan waktu proses, kemudahan mendapatkan pelayanan (Sundari,2017)

Pengakuan terhadap keprimaan sebuah pelayanan, bukan datang dari aparatur yang memberikan pelayanan, melainkan datang dari pengguna jasa layanan, kualitas yang baik bukanlah berdasarkan sudut pandang atau persepsi penyedia jasa, melainkan berdasarkan sudut pandang atau persepsi pelanggan. Pelangganlah yang mengkonsumsi dan menikmati jasa, sehingga merekalah yang seharusnya menentukan kualitas pelayanan umum. Persepsi pelanggan terhadap kualitas jasa atau pelayanan merupakan penilaian menyeluruh atas keunggulan suatu pelayanan (Kurniati,2020) 


\section{Yayah Khoeriah, Sri Dinengsih, Risza Choerunnisa}

\section{Hubungan Assurance dengan Tingkat Kepuasan Ibu Hamil}

Berdasarkan hasil analisis nilai Assurance $p=0,000$ maka dapat disimpulkan penelitian ini ada hubungan yang signifikan antara kualitas pelayanan antenatalcare assururance dengan tingkat kepuasan ibu hamil dengan nilai OR 140.8 maka disimpulkan bahwa kualitas pelayanan antenatal care assururance yang kurang baik mempunyai kecenderungan untuk mengalami ketidakpuasan pada responden 140 kali lebih besar dibandingkan dengan kualitas pelayanan antenatal care assururance yang baik

jika pelayanan kesehatan tidak dapat memberikan jaminan mutu yang sesuai dengan harapan ibu hamil maka akan menurunkan kepuasan masyarakat hingga Pada akhirnya masyarakat tidak akan memanfaatkan ulang dari pelayanan yang diberikan (Mursyidah,2012)

Ada keterkaitan yang cukup kuat antara persepsi ibu hamil Mengenai mutu layanan ANC pada dimensi assurance (jaminan) dengan tingkat kepuasan pasien. Semakin kurang baik persepsi pasien terhadap mutu layanan ANC pada dimensi assurance (jaminan) maka semakin tidak baik tingkat kepuasan ibu hamil terhadap layanan ANC jika dimensi assurance dilaksanakan tidak sesuai dengan harapan ibu hamil maka akan membuat ibu hamil berpersepsi kepuasan tidak baik.(Suryadi,2017)

Penentuan suatu kualitas pelayanan yang diberikan merupakan penilaian dari penerima jasa berdasarkan sudut pandang dan persepsi pelanggan atas jasa pelayanan yang didapatkan. Persepsi penilaian pelanggan terhadap pelayanan yang diberikan merupakan penilaian menyeluruh dari suatu penilaian pelayanan yang diberikan sehingga dapat dikatakan bahwa suatu pelayanan yang berkualitas adalah pelayanan yang berdasarkan pada kepuasan pelanggan. Jika suatu kepuasan tercipta maka persepsi suatu pelayanan yang berkualitas akan tumbuh(Kurniati,2020)

\section{Hubungan Empaty dengan Tingkat Kepuasan Ibu Hamil}

Didapatkan nilai $P$ value ; 0.000 Artinya ada hubungan yang signifikan antara kualitas pelayanan antenatalcare empathy dengan tingkat kepuasan ibu hamil dengan nilai OR 140.8 dapat disimpulkan bahwa kualitas pelayanan antenatal care empathy yang kurang baik mempunyai kecenderungan untuk mengalami ketidakpuasan pada responden 140 kali lebih besar dibandingkan dengan kualitas pelayanan antenatalcare empathy yang baik.

Perhatian (emphaty) yaitu memberikan perhatian yang tulus dan bersifat individual atau pribadi yang diberikan kepada para pelanggan atau pasien dengan berupaya memahami keinginan konsumen. Dimana suatu Rumah Sakit diharapkan memiliki pengertian dan pengetahuan tentang pelanggan, memahami kebutuhan pelanggan secara spesifik serta memiliki waktu.(Febriani,2012)

Empathy ( perhatian individual kepada pelanggan ), yaitu memberikan perhatian yang tulus dan bersifat individual atau pribadi yang diberikan para pelanggan dengan berupaya memahami keinginan pelanggan. Dimana suatu perusahaan diharapkan memiliki pengertian dan pengetahuan tentang pelanggan,memahami kebutuhan pelanggan secara spesifik,serta memiliki waktu pengoperasian yang nyaman bagi pelanggan(Aryska, 2017

Ukuran kepuasan pelanggan memberikan umpan balik mngenai seberapa baik penyedia layanan melaksanakan tugasnya Sedangkan hal ini bermakna dalam mencapai kesuksesan,RS harus mampu memastikan kebutuhan dan keinginan konsumenya dan semua itu tergambar dalam pelayanan yang dilakukan(Aryska, 2017)

bahwa Rumah Sakit khususnya karyawan dapat memberikan perhatian kepada konsumen secara individu, termasuk juga kepekaan akan kebutuhan konsumenserta karyawan dapat meningkatkan kemampuan melakukan penyampaian informasi kepada konsumen atau memperoleh masukan dari konsumen dan pemahaman untuk mengetahui dan memahami kebutuhan dan keinginan konsumen.

\section{SIMPULAN}

Ada hubungan yang signifikan antara tangible, realibility, responsiveness, assurance, empathy terhadap pelayanan ANC dengan tingkat kepuasan pada ibu hamil dengan nilai $p$-value < 0,05 dengan variabel yang paling dominan adalah di tangible dan assurance (OR 140.8)

\section{SARAN}

Diharapkan kepada petugas kesehatan supaya meningkatkan konseling terhadap ibu hamil untuk melakukan kunjungan ANC secara teratur.

\section{DAFTAR PUSTAKA}

Umaternate, T. S., Kumaat, L., \& Mulyadi, N. (2015). Hubungan Pelaksanaan Identifikasi Pasien Secara Benar Dengan Kepuasan Pasien Di Instalasi Gawat Dadurat (lgd) 


\section{JKM (Jurnal Kebidanan Malahayati),Vol 7,No.4.Oktober 2021, \\ ISSN (Print) 2476-8944 ISSN (Online) 2579-762X, Hal 620-625}

Rsup Prof. Dr. RD Kandou Manado. Jurnal Keperawatan,

Sundari, L. (2017). Hubungan Kepuasan Pasien dengan Kualitas Pelayanan Antenatal Care (ANC) oleh Bidan Jejaring BPJS di Wilayah Kerja Puskesmas Warungasem Kabupaten Batang (Doctoral dissertation, Universitas Muhammadiyah Semarang).

Izati, A. R. M. (2018). Trend Cakupan Kunjungan Ibu Hamil (K4) Dan Pertolongan Persalinan Oleh tenaga Kesehatan Di Propinsi Jawa Timur. Jurnal Ilmiah Kesehatan Media Husada, 7(1), 1-10.

Florensia Lawani, J. E. S. S. I. C. A., \& Aliviani Putri, R. (2021). Faktor-Faktor Yang Berhubungan Dengan Kunjungan K4 Di Puskesmas Katomaliga Beteleme, Kecamatan Lembo, Kabupaten Morowali Utara, Sulawesi Tengah (Doctoral Dissertation, Universitas Ngudi Waluyo).

Profil Kesehatan Indonesia 2019, Kemenkes 2020

Maulana, A. F. Gambaran Kualitas Pelayanan Antenatal Pada Ibu Hamil Di Puskesmas Pagedangan Kabupaten Tangerang Tahun 2017 (Bachelor's thesis, UIN Syarif Hidayatullah Jakarta: Fakultas Kedokteran dan Ilmu Kesehatan, 2017

Nissa, A. A., \& Mardiyaningsih, E. (2013). Gambaran Kepuasan Ibu Hamil terhadap Pelayanan Antenatal Care di Puskesmas Getasan Kabupaten Semarang. Jurnal Keperawatan Maternitas, 1

Mursyida, R. F., Mawarni, A., \& Agushybana, F. (2012). Kepuasan ibu hamil dan persepsi kualitas pelayanan antenatal care di puskesmas tanjung kabupaten sampang madura. Media Kesehatan Masyarakat Indonesia, 11(2), 174-181.

Suryadi, Y. (2017). Analisis Pengaruh Persepsi Mutu Layanan Antenatal Care (ANC) Terhadap Kepuasan Ibu Hamil Di Puskesmas Lamepayung Kabupaten Kuningan Tahun 2009. Syntax Literate; Jurnal IImiah Indonesia, 2(4), 133-145.
Sampouw, N. L. (2018). Hubungan Kualitas Pelayanan Antenatal Care Dengan Kepuasaan Ibu Hamil. Jurnal Skolastik Keperawatan, 4(2), 32-48.

Kurniati, C. H. (2020). Hubungan antara kualitas bidan dalam pelayanan antenatal care terhadap persepsi ibu hamil. Infokes: Jurnal IImiah Rekam Medis dan Informatika Kesehatan, 10(1), 36-40.

Febriani, V. A., \& SUGIONO, S. (2012). Analisis Pengaruh Kualitas Pelayanan Terhadap Kepuasan Konsumen (Studi Pada Pasien Poliklinik Rawat Jalan Rumah Sakit Dr. Cipto Mangunkusumo) (Doctoral Dissertation, Fakultas Ekonomika Dan Bisnis).

Aryska, M., \& Kasmirudin, K. (2017). Pengaruh Reputasi Perusahaan dan Kualitas Pelayanan Terhadap Kepuasan Pasien (Kasus Rumah Sakit Islam Ibnu Sina Pekanbaru) (Doctoral dissertation, Riau University).

Lestari, T. A., \& Kurniawan, L. (2018). Analisis Kualitas Pelayanan Kesehatan Ibu Hamil Dan Melahirkan Pada Puskesmas Poned Kota Semarang. Journal Of Public Policy And Management Review, 7(2), 402-425.

Fhirastika, H., 2016, Studi Mengenai Tingkat Kepuasan Pasien AntenatalCare (ANC) Terhadap Mutu Pelayanan Kesehatan Di Wilayah Kerja Kecamatan Somba Opu Kabupaten Gowa, Skripsi, Program Studi Kedokteran Universitas Negeri Islam Allaudin. Sulawesi

Gerson, S., 2014. Manajemen Pelayanan Kesehatan, EGC, Jakarta.

Handayani, F., 2018, Hubungan Kualitas Pelayanan AntenatalCare (ANC) dengan Tingkat Kepuasan Ibu Hamil Yang Menggunakan BPJS di Puskesmas TOILI Kabupaten Banggai Provinsi Sulawesi Tengah, Skripsi, Program Studi Sarana Terapan Kebidanan Universitas Nasional, Jakarta

Irwan., 2012, Pendekatan Mutu dan Kepuasan Pelanggan Dalam Pelayanan Kesehatan, Program Pasca SarJana UNHAS 